\title{
Christopher Beeston and the Caroline Office of Theatrical 'Governor'
}

The decision in February 1637 to appoint Christopher Beeston (alias Hutchinson) 'Gouuernor of the new Company of the Kings \& Queenes boyes' crowned one of the busiest and most innovative careers in seventeenth-century commercial theatre. ${ }^{1}$ Beeston had emerged in the 1590 s as a young performer in the Chamberlain's Men, notably acting with Richard Burbage, William Kempe, and William Shakespeare in the first production of Ben Jonson's Every Man in His Humour. For the better part of the next two decades, he managed the financial affairs of Queen Anne's Men at the Red Bull and with that company's assets at his disposal, particularly its valuable wardrobe, he oversaw the building of west London's first playhouse in 1616 — the Cockpit (or Phoenix) in Drury Lane. By 1636, Beeston had established himself as London's pre-eminent theatrical entrepreneur, having led Queen Henrietta Maria's fashionable company for ten years and amassed an unprecedented personal treasury of playbooks, acting apparel, and other tiring house materials. However, in May of that year the worst outbreak of plague in three decades closed the theatres and suppressed business until the following October 1637. Under the stress of eighteenth months of enforced idleness, acting companies buckled, setting patents and personnel adrift. Among the casualties was Beeston's relationship with the Queen's Men. From his vantage point at the competing Salisbury Court theatre, Richard Heton observed that: 'When her $\mathrm{m}^{\text {ts }}$ servants were at the Cockpitt, beinge all at liberty, they disperst themselves to severall Companies, so that had not my lo: of Dorsett taken Care to make vp a new Company for the Queene, she had not any at all'. $^{2}$ Another onlooker, Dorothy Blagrave, wife of the deputy Master of the Revels, claimed that Beeston had deliberately antagonized his colleagues, 'to the end hee might have a Company that would take what hee would be willing to give them'. ${ }^{3}$ The Cockpit's owner soon emerged from these troubles to lend his name to a troupe of boys performing at St. James's palace on 7 and 
14 February $1637 .{ }^{4}$ It was at the conclusion of these revels one week later, on 21 February, that a clerk in the Lord Chamberlain's office registered the warrant entitling Beeston to 'govern' a newly-patented young company. The dormant London theatres briefly re-opened on 24 February and, according to the Master of the Revels, Beeston's 'company of boyes ... began to play at the Cockpitt', while prominent members of the old Queen's Men and their patent were moved to the playhouse in Salisbury Court. ${ }^{5}$ Almost immediately, plague once more restricted public playing but when the prohibition was lifted in the autumn of 1637, and steady business again resumed, the King and Queen's Young Company flourished, confirming Beeston's status as Caroline London's foremost man of theatrical business.

Beeston's office of theatrical governor was undoubtedly the culminating achievement of his late career; yet the circumstances underlying its creation and its relation to the unusual professional developments of 1636 and 1637 remain obscure. Generally, theatre historians agree that a power struggle of some form late in 1636 precipitated the disbanding of Beeston and the queen's actors. The observations recounted by Heton and Blagrave led G.E Bentley to conclude that Beeston conspired 'to get rid of one company at his theatre and to start another', an end he achieved forcibly during the long plague closure by 'evicting his old tenants', thereby 'consolidating his dominant position' at the Cockpit. ${ }^{6}$ Andrew Gurr similarly suggests that Beeston 'dislodged' and 'dismissed' the Queen's Men, finding the move indicative of an 'autocratic form of rule' that had begun to take hold in London as a dominant institutional practice. In an emergent Caroline 'impresario system', he argues, theatre owners came to recognize that an organization composed mainly of juveniles - like the company of His Majesty's Revels that Richard Gunnell and William Blagrave formed in 1629 - was more financially dependent, and therefore more obedient, than a cooperative of adult sharers along the lines of the King's Men. It was in this commercial context, Gurr suggests, and in an effort to bring his Drury Lane enterprise more strictly under his control, that Beeston strategically abandoned the adult Queen's Men and 'secured his new patent' to govern a company of boys. ${ }^{7}$

Although this narrative remains compelling, it raises critical questions about the authority required to dissolve and reconstitute acting companies. Was an individual sharer, even one as apparently strong-willed as Beeston, capable of breaking apart the patented Queen's Men? If so, who authorized his decision and how was his post as the governor of his new company subsequently 'secured'? Martin Butler has recently proposed that the suc- 
cess of Beeston's ambitious contrivances at this time may owe as much to 'powerful friends' as to the ruthless commercial instincts theatre historians attribute to him. 'If Beeston was acting as impresario,' Butler suggests, 'he could do so only because of a hand-in-glove relationship with great authorities at Whitehall. ${ }^{8}$ New evidence strongly supports this observation. Previously unexamined records concerning Beeston's property and finances in the 1630s reveal that he was repeatedly involved in the affairs of the aristocratic Herbert family - particularly of Philip Herbert, the fourth earl of Pembroke. As Lord Chamberlain of the king's household and a nobleman of considerable political influence at court, Pembroke was uniquely positioned to authorize any managerial changes that Beeston may have pressed for in 1636 and 1637. The earl's patronage, furthermore, appears to have been a critical factor in Beeston's appointment as governor of the King and Queen's Young Company in 1637.

Beeston's nominal patrons for over thirty years were members of the Stuart royal family. As an actor and company manager, he served the households of Queen Anne from 1604 to 1619, Prince Charles to 1622, Lady Elizabeth to 1624, and Queen Henrietta Maria thereafter. The everyday complexities of the London theatre business necessitated numerous professional and political connections, however, and Beeston carefully cultivated relationships with a variety of social superiors, the most influential of whom belonged to the Herbert family of Montgomery and London. Theatre historians have long been aware of one of these significant points of contact. Between 1623 and 1638, Beeston worked steadily and cordially with Sir Henry Herbert, the Master of the Revels. Herbert's responsibility was to supervise and license all aspects of the theatre owner's enterprise, and the surviving remnants of his office-book illustrate the due reverence Beeston afforded him during their fifteen years of regular interaction. In 1632, for instance, when caricatures of English courtiers seriously offended Herbert during the readying of James Shirley's comedy The Ball, Beeston 'promiste many things that [the Master] found faulte withall should be left out' and assured him 'he would not suffer it to be done by the poett any more'. Similarly, in 1634, when asked to host a company of visiting French actors at the Cockpit on behalf of their royal sponsors, Beeston is said to have 'obeyd readily', to Herbert's obvious satisfaction. ${ }^{9}$ Ready obedience in such moments was of course rational and professional but something more complex also seems to have been taking place below the surface, structuring relations between the two men. 
Beeston's practice of supplementing Herbert's standard fees brings another dimension of their relationship into focus. Like John Heminges, Richard Gunnell, and other company administrators, he dutifully paid Herbert 'Occasionall Gratuityes', small sums of money that acknowledged professional courtesies such as the approval of a play-list for court revels. ${ }^{10}$ But at the same time, in an evidently unique habit, he also gave Herbert distinct, non-monetary 'gifts' which exceeded the Master's normal perquisites. On 10 March 1623/24, for example, he delivered 'Sir Walter Rawleys booke worth $1^{\text {li' }}$ to the Revels Office as a 'Newyeres gift'. ${ }^{11}$ And following a rendezvous to conduct business in the summer of 1633 , Herbert describes an even more elaborate presentation:

Received of Biston, for an ould play called Hymen's Holliday, newly revived at their house, being a play given unto him for my use, this 15 Aug. 1633, [£3]

... Meetinge with him at the ould exchange, he gave my wife a payre of gloves, that cost him at least twenty shillings. ${ }^{12}$

Herbert here suggestively appends his memorandum about the gift of gloves to a record of having licensed a play 'given unto [Beeston] for my use'. He does not state the 'use' he has in mind, nor the precise nature of Beeston's involvement but it seems reasonable to speculate that he had enlisted Beeston's expertise to privately stage the old play, perhaps, given its title, to celebrate the nuptials of someone in his social circle. Certainly the entry hints at a more complex and reciprocal partnership between the two men than is normally assumed and calls into question existing characterizations of Beeston's gifts as 'good investments', 'blandishments of the censor', or bribes calculated to 'stay on the good side' of a man of influence. ${ }^{13}$ More precisely, Beeston's gifts have the appearance of a client's traditional offerings to a sponsor. Social and economic historians have amply demonstrated that patronage structured most forms of business in the seventeenth century. Personal connection was the primary mechanism by which a person realized entrepreneurial or artistic talents and gifts functioned as nurturing instruments in this system, testifying to a patron's honour and power while serving as a reminder of the obligation to bestow favour upon a client. ${ }^{14}$ Something other than unsophisticated commercial self-interest may well have motivated Beeston's liberality toward the Master of the Revels, therefore; indeed, if we recast Herbert as Beeston's 'friend' — that is, his link to a wider patronage network maintained by the influential Herbert family — the encoded meanings likely communicated by his tokens 
become clearer: Raleigh's folio History of the World respectfully acknowledges the intellect on which Sir Henry prided himself, while the gloves given to his wife Susan signal his fidelity to the larger Herbert clan. ${ }^{15}$

New information about Beeston's money and property supports the likelihood that he looked to the Herbert family for patronage. By building the Cockpit in the western parish of St. Giles-in-the-Fields, Beeston probably aimed to capture a theatrical market stimulated by the growing population and circumambient wealth of Westminster. Also evident now is the fact that he sought to capitalize on the area's rising demand for accommodation. By the 1630s, the suburbs and fields surrounding the Cockpit were thick with speculators and builders working to renovate or construct new lodgings for the many gentle families, office-holders, and place-seekers striving to settle in the vicinity of nearby Whitehall. With capital at his disposal - presumably revenue generated by his theatrical business - Beeston involved himself in the development of two landmarks of Caroline London.

The first of these was Covent Garden, transformed from a grassy pasture into a Parisian-style civic space by the earl of Bedford in 1631. His scheme involved leasing parcels of the site to speculators who then bore the cost of building architecturally-uniform residences around its neoclassical centrepiece, the new St. Paul's chapel and adjoining piazza designed by Inigo Jones. Bedford's lessees were primarily speculating tradesmen, many with court connections. ${ }^{16}$ Using his Hutchinson alias, Beeston bought two leases to the joined lots (numbers 6 and 7) at the southeast end of newly-laid out Henrietta Street. ${ }^{17}$ By 1634, he had raised a pair of three-storied, arcaded houses of brick facing the south wall and churchyard of the chapel, with a view onto the piazza to the northeast. His will later put the value of these "Twoe howses lately erected and built, in Couent Garden" at $£ 600 .{ }^{18}$ Bedford's plan had been to establish a socially-elevated neighbourhood of gentlemen and men of ability and Beeston obliged by taking William Herbert, first Baron Powis, for his tenant at 7 Henrietta Street. ${ }^{19}$

Powis hailed from the Welsh Marches but was frequently in London. As a parliamentary representative of Montgomeryshire in the 1620s, he ardently promoted the interests of his namesake, the third earl of Pembroke, a service that helped to earn him his title in $1629 .{ }^{20}$ For much of Charles's personal rule, he was at leisure in the city and may have been a regular playgoer. ${ }^{21}$ That his son-in-law was the poet William Habington, a close friend of Beeston's frequent collaborator Shirley, may account for his association with the theatre owner. ${ }^{22}$ The more pertinent connection, however, was probably the one between Powis 
and his first cousin, Philip, the fourth earl of Pembroke. Having inherited his brother's office of Lord Chamberlain in 1626 and his earldom in 1630, Pembroke was Powis's most consistent and powerful ally at court throughout the 1630s. ${ }^{23}$ A newsletter written about the time the baron took up residence in Covent Garden captures the flavour of their intimate, sometimes stormy relationship. As they dined together early in 1634, it recounts, a quarrel erupted between the two noblemen; Pembroke, famously hot-tempered, shouted, 'See how this Rascal, that cannot eat Bread without me, useth me,' to which Powis reportedly 'made so sharp a Reply, that the whole Table was forced to rise, to keep them asunder'. ${ }^{24}$ Powis was a devout catholic and Pembroke a man of reformed conviction, which perhaps contributed to the customary friction between them. Religion would prove a serious point of contention in 1637 when the earl strongly advocated a proposal before the Privy Council to "take away the eldest Sons of all who were popishly affected, and breed them up in the Religion established in the Church of England' - a policy that threatened to remove the baron's grandson from his son's household. ${ }^{25}$ The durability of kinship nevertheless prevailed and Powis's catholic descendants remained in line to inherit Pembroke's massive estate. Possibly, religious affiliation connects Powis directly to Beeston who was a known recusant with ties to London's catholic community. But, given the theatre manager's familiarity with the Herberts in the Revels Office, and given the crucial part social connection played in the procurement of housing in London's competitive market, the stronger likelihood is that Pembroke arranged his cousin's tenancy in Beeston's new, desirable townhouse.

Further evidence suggests that Beeston served Pembroke in a non-theatrical capacity in 1634 . That summer, a violent quarrel among gentlemen provoked the king to bar public access to the Spring Garden, near Whitehall. The royal pleasure garden had long been a popular resort for walking, bowling, and 'drinking Wine all day under the Trees' and its enterprising groundskeeper, Simon Osbaldeston, wasted no time obtaining a license to create 'a new Spring-Garden' with which 'to entertain Gamesters and Bowlers, at excessive rate' ${ }^{26}$ At the northeast corner of the Haymarket in St. Martin's-in-the-Fields, on a pasture known as Scavenger's Close, Osbaldeston oversaw construction of an imposing brick gaming house, soon to be known as Shaver's Hall. Ornate wooden stairs within led up to rooms set out for cards, dice, and dining; above these, terraced lodging chambers overlooked 'a pleasant prospect' of a 'faire Tennis Court' and 'fayre Bowling Alleys, Orchard gardens, gravily walks, and other green walks. ${ }^{27}$ Magnificence of this sort was 
costly, with building and landscaping expenses reportedly exceeding $£ 5000 .^{28}$ Osbaldeston financed much of the work on credit and his failure to repay his debts later provoked legal action on several fronts. A surviving answer to a bill of complaint in one of these suits reveals that, while financing his venture, Osbaldeston relied upon the assistance of Christopher Beeston. ${ }^{29}$

The project was already underway in 1634 when Osbaldeston and a group of partners negotiated to borrow $£ 4136 \mathrm{~s} 8 \mathrm{~d}$ from a distinguished resident of nearby Chelsea, Sir John Danvers. A loan of that size required security and, as Beeston's wife, Elizabeth, later explained:

Christofer Beeston ... this Defendantes deceased husbande ... was drawne and persuaded to enter into the bond ... vnto the sayd Sir Iohn Danvers as suerty with the sayd Symon Osbaldeston ᄀvpon the promise of the said Symon Osbaldeston 7 and the said defendantes Iohn Barrowe and Thomas Osbaldeston to give him the sayd Christofer Beeston counter securyty by bond to save him harmeles against the said principal bond. ${ }^{30}$

She does not state how her husband was 'drawne and persuaded' to reinforce the Shaver's Hall syndicate but the pattern of affiliation that emerges suggests a plausible answer. Simon Osbaldeston was the earl of Pembroke's gentleman barber and his gaming house licence was the latest of several lucrative commissions awarded him by his master for loyal service. ${ }^{31}$ John Barrowe was also Pembroke's creature and owed the earl his position as the king's falconer and as a verderer in the royal forest of Dean. ${ }^{32}$ Sir John Danvers, Osbaldeston's creditor, had married Sir Henry Herbert' mother Magdalene in 1609 and was another of Pembroke's clients. ${ }^{33}$ Pembroke's own attitude to the venture was not apparently disinterested; the letter-writer Gerrard noted in 1635 that "My Lord Chamberlain much frequents that Place, where they bowl great Matches' and the following spring he remarked upon the earl's concern for the hall's reputation:

Simme Austbistons house is newly christned, It is calld, Shauers Hall, ... At first noe conceyte there was, of the builders beinge a Barber; but it came vpon my Lord of Dunbarrs loseing $3000^{\mathrm{li}}$ at one sitting; wheron they said a Northerne Lord was shaued there; But now Putting both togeather, it will be a Nickname of the Place ... My Lord Chamberlayne knows not of yett; but hele chafe abominably when he comes to know yt. ${ }^{34}$ 
Beeston's financial pledge on behalf of this dense grouping of Pembroke's servants is suggestive and arguably represents another courtesy to the Herbert family. Indeed, if his association with the gaming house investors reflects his own status as one of Pembroke's clients - like Osbaldeston, like Berrowe, and like Danvers — he may well have been 'drawne and persuaded' to participate by the earl himself.

This pattern of social and financial connection to the Herberts invites us to reexamine the striking changes undergone by the professional theatre in 1636 and 1637. By the time the London playhouses had closed in the spring of 1636, the internal dynamic of Queen Henrietta Maria's company seems to have become unstable. Michael Bowyer, William Allen, Theophilus Bird and other younger actors of the 1620s had begun to assume leading parts in place of aging veterans such as Richard Perkins, William Sherlock, and John Sumner. A new generation of acting apprentices was also distinguishing itself, led by sixteen-year-old Ezekiel Fenn, reputed to be of extraordinary ability. ${ }^{35}$ These polished younger actors seem to make their presence felt especially in plays newly written for the Cockpit in the months just prior to the plague closure, with their emphases on female characters, vocal performance, choreographed procession, and stage dance. Thomas Nabbes's Hannibal and Scipio, for instance, introduces Fenn in the central female role of Sophonisba with a call for 'Musicke' and a train of 'Ladies all in white, and veil'l: who to the musicke of the song, place themselves in a figure for the daunce'; at its conclusion, they 'discover themselves in order, Sophonisba last'. Shirley's final play for Beeston was The Duke's Mistress, licensed on 18 January 1636. In its second act, the Duke and Ardelia enter accompanied by 'Musicke, and Song in Dialogue', closely followed by three anonymous 'Ladies' who dance at length with the courtiers Leontio, Strozzi, and Silvio. John Ford's The Fancies Chaste and Noble twice prompts the 'art in motion' of dance and presents a wedding procession, '[p]assing neat and exquisite', at which a group of ladies 'turne Songsters'. And in Henry Glapthorne's The Hollander, licensed on 12 March 1636, one month before the closure, an elaborate interlude calls for the Cockpit music to play 'through the doore' while several characters 'frisk' about the Dutch gallant Sconce in an absurd 'Twibill dance' designed to steal his clothes. ${ }^{36}$ Examples such as these make it not unreasonable to suspect that the dysfunction soon to grip the Queen's Men was rooted in the emphatic display of younger actors at the expense of veterans. ${ }^{37}$

If Beeston did want to replace his existing company with a new one, as Bentley and Gurr argue, he may have found it a challenge. Ownership of the 
playhouse was certainly to his advantage; antagonists might simply have been barred access to his stage and playing materials. But no evidence confirms that he possessed the authority to deny fellow actors their liveried status, at least not yet. The complication of 1636 probably therefore had the effect of polarizing, even paralyzing, the queen's company, but not breaking it. Some actors must have become estranged, presumably those veterans soon to migrate to Heton's theatre at Salisbury Court - Perkins, Turner, Sumner, and Sherlock. Others remained loyal to Beeston, certainly his son-in-law, Bird, and those young men bound to his household, as probably was Fenn. ${ }^{38}$ If this scenario is correct, then the Queen's Men were in disarray when the court revels began in the winter of 1636 but not extinct, their ranks divided but their official status essentially unresolved. This state of affairs remains consistent with Heton's remark that some of the Cockpit actors found themselves 'at liberty' and so 'disperst themselves'; it also conceivably informs Blagrave's cryptic charge that Beeston wanted 'a Company that would take what hee would be willing to give them'.

If the Queen's Men were in professional limbo around the turn of 1637, what then was the status of the actors Beeston led at court that winter? 'Beeston's Boys' are typically thought to have been the product of a well-plotted management strategy, formed in anticipation of the Queen's Men's demise, and intended at their inception for royal patronage. As is often true, however, skilful improvisation may have shaped events more than meticulous planning. According to Herbert's records, the King's Men busily provided the bulk of the court's dramatic entertainment that Christmas, acting all of the recorded court plays between 26 December and 31 January 1636/37. The absence of the Queen's Men probably did not go unnoticed since its regular appearances stretched back to the mid-1620s. Beeston's actors were recorded twice that February and, going by Herbert's inconsistent nomenclature, there was something unconventional about their status:

Cupides Revenge, at St. James, by Beeston's boyes, the 7 Febru.

Wit without Money, by the B. boyes at St. James, the 14 Feb. ${ }^{39}$

If this company were a long-gestating, well-practiced troupe, why was it not exhibited earlier? Its late appearance, in the two weeks before the revels wound down, suggests that it may have been instead a rather hastily assembled group, perhaps cobbled together only after final efforts to reconcile the 
Queen's Men failed in December or January. If so, the 'boyes' to which Herbert refers were likely an ad hoc assemblage of Beeston loyalists from among the queen's actors, many obviously youthful, rounded out with hired men. Herbert's phrasing — 'Beeston's boyes' - appears nowhere else in extant theatrical records. Its disproportionately frequent use by modern scholars, coupled with the routine assertion that the Caroline public adopted the name colloquially, has solidified the impression that Beeston's court actors were a finished, formal company. ${ }^{40}$ It is certainly possible that Beeston telegraphed the potential impact of 'boyes' that season. His selection of Cupid's Revenge and Wit without Money from his repertory reflects that season's courtly vogue for Beaumont and Fletcher revivals and both plays contain opportunities to display the singing and dancing talent of his young stable. ${ }^{41}$ The queen was eight months into her fifth pregnancy in February, perhaps also contributing to an atmosphere more than normally receptive to the charms of young performers. ${ }^{42}$ Managerial considerations such as these, however, would have been futile had Beeston not first secured a place at the festivities. The Master of the Revels and the Lord Chamberlain were responsible for selecting the court's entertainers and we may assume they did so with their obligations as patrons firmly in mind. Beeston's access to the court that winter was for this reason assured, to the detriment of any other faction of the troubled queen's company.

Herbert's patronage must also have prompted the speedy licensing of the 'boyes' and Beeston's concurrent appointment as their governor seven days later. Like other minor offices in the king's household, the new post was specifically within the Lord Chamberlain's gift and circumstances suggest that it was conceived as part of a larger policy to resolve the lingering problem of the destabilized queen's company. In consultation with the earl of Dorset, the queen's chamberlain, Pembroke sought to redistribute royal patronage equally throughout London's three operative hall playhouses: the King's Men had passed through the disorders of the plague in relative stability and would continue at their Blackfriars auditorium; the fractured Queen's Men and their patent were reconstituted at the playhouse in Salisbury Court (where Dorset held an interest); and to fill the gap that remained in Drury Lane, Pembroke brokered for Beeston the king and queen's combined patronage and an opportunity to manage a new, young company in their name.

An establishment-list of 1641 represents the theatrical governor's distinct standing within the king's household. In prestige, it was comparable to the great crowd of limners, librarians, clothing surveyors, herbalists, organ 
keepers, and perfumers who made up the lower tier of chamber service but, in practical terms, it apparently established for Beeston something like an adjunct position in the Revels Office:

\author{
Revells \\ $S^{r}$ Henry Herbert $M^{r}$ \\ Alexander Stafford Clarke \\ Ioseph Taylor yeoman \\ Geo: Wilson Groome \\ Gouernor of $y^{e}$ Cockpitt Players \\ William Bieston \\ Bowes \\ Lodowick Carlile gent ${ }^{` 43}$
}

Integration into the Revels hierarchy likely brought modest wages and allowances as well as a ticket of privilege. ${ }^{44}$ More significantly, it gave Beeston the opportunity to codify his managerial practices and innovations (as autocratic as they might be) and to operate his commercial enterprise with greater, institutionally-sanctioned authority; indeed if the word 'governor' carried its seventeenth-century educational connotation, the office may have been recognized as a mechanism for transmitting skill and nurturing young actors for future royal service. ${ }^{45}$

By all accounts, the office was inextricable from the Cockpit and, possibly, the Lord Chamberlain and Master of the Revels viewed that theatre's rich tiring house as a useful new resource with which to supplement their outdated Revels budget. ${ }^{46}$ Pembroke's more immediate concern, however, was to clearly delineate Beeston's managerial prerogatives in order to prevent further disorders such as had paralyzed the Queen's Men. Only in his new position does Beeston finally appear to have acquired the authority to make and break acting companies. Even then, Pembroke vetted the process, as is evident in the detailed warrant he issued William Davenant in June 1640:

I doe authorize and appoint William Dauenant Gent' ... to take into his Gouernmment \& care ... [the King and Queen's Young Company] to gouerne, order \& dispose of them for Action and presentments, and all their Affayres ... as in his discretion shall seeme best to conduce to his Majesty's seruice in that Quality... . Which power or prevelidge Hee is to continue $\&$ injoye ... Provided he bee still accomptable to mee for his care $\&$ well orderinge of the sayd Company. ${ }^{47}$ 
In return for accountability, the Lord Chamberlain protected the Governor's commercial interests. In the spring of 1637 , when the plague again seized London, Beeston rather boldly defied the renewed order against playing and publicly exercised his actors. On 12 May 1637, the Privy Council summoned him to explain his insubordination and one imagines that he addressed his responding petition more or less directly to Pembroke:

your Petitioner being commanded to erect and prepare a Company of young Actors for their Majesties's seruice, \& desyrous to know how they had profetted by his instructions, Hee inuited some noble Gentlemen to see them Act att his Howse the Cockpitt. For which (since he perceaues it is imputed a fault) hee is uery sorry, humbly crauing your Honnourable pardon, \& promiseth not to offend in the like Nature. ${ }^{48}$

Beeston's emphasis on his status as a royal servant and on his affiliation with "noble Gentlemen" strikes a balanced note of deference and confidence. That there were no apparent consequences to his infraction seems to confirm the privileged environment in which he was now working.

During the five years that followed, the word 'governor' began to displace 'master', 'chief', 'steward', and 'warden' as a preferred term of authority in the professional idiom. Inflected by its courtly origin and unambiguously connoting a power to order, the word clearly impressed Beeston's competitor Richard Heton. In the spring of 1639, he drafted a document entitled 'Instructions for my Pattent', outlining a set of rules and prerogatives by which he hoped to structure affairs at the playhouse in Salisbury Court. His foremost priority was to be recognized as the 'sole governo ${ }^{\mathrm{r} \text { ' }}$ of the theatre's actors, a position that would enable him 'to select, order, direct and sett upp land governe/ a Company of Comedians' and to direct their business affairs. Toward the end of the document, his rhetorical stress on 'governing' intensifies. After considering 'such of the Company as will not be ordered and governed by me as their governo ${ }^{\mathrm{r}}$, , he entreats for the 'power to dischardge [these disobedient actors] from the Company, and $\mathrm{w}^{\text {th }}$ the Advice of the $\mathrm{m}^{\mathrm{r}}$ of the revells to putt new ones in their places'. ${ }^{49}$ Undoubtedly, this recalls privileges already granted to Beeston.Yet Heton's proposed patent seems never to have materialized because he lacked the particular advantage of social and financial ties with decision makers in the Revels Office. Indeed, by the 1630s, an aspiring impresario's need for the backing of personal patrons appears to have become paradigmatic. ${ }^{50}$ 
Scholars such as Bentley, Gurr, and Butler have clearly demonstrated that Christopher Beeston's career is central to an understanding of the developing world of commercial theatre management in the early seventeenth-century. In 1637, in a definitive moment in this career, the Cockpit's owner was granted the court office of governor of the King and Queen's Young Company. I have argued that Beeston's privileged status as a client of the aristocratic Herbert family facilitated this preferment. As the new evidence presented here suggests, his social and financial involvement with the Herbert family in non-theatrical building projects such as Covent Garden and Shaver's Hall exposed him to opportunities to cultivate the patronage of men uniquely positioned to promote his theatrical interests. Recognizing the importance of personal patronage to Beeston's managerial success requires us to modify the conventional image of the impresario as a ruthless, market-driven autocrat. Like James Burbage, Philip Henslowe, Edward Alleyn, and other Elizabethan and Jacobean entrepreneurs before him, Beeston clearly understood the need to discretely and pragmatically negotiate the existing system of patronage in order to better ensure the stability of his commercial enterprise. He was, properly, an amphibious creature, as carefully adapted to the courtly ambit of Whitehall as to the theatrical marketplace of Drury Lane. The office established on his behalf in 1637 would not long survive him, its authority going the way of the Stuart court during the civil wars of the next decade. Theatrical leaders of the Restoration would knowingly work to reinstate some of its prerogatives as they set up their court-aligned enterprises under Charles II. However, before the end of the century, the Caroline concept of the theatrical 'governor' would give way to the newer, preferred linguistic designation of 'manager'.

\section{Notes}

Research for this article was completed with the assistance of a George C. Metcalf Fellowship from Victoria University in the University of Toronto.

1 E.K. Chambers (ed.), 'Dramatic Records: The Lord Chamberlain's Office', Malone Society Collections 2.3 (1931), 382. For the scope of Beeston's career, see G.E. Bentley, The Jacobean and Caroline Stage, 7 vols (Oxford, 1941-68), 2:363-70, and Andrew Gurr, 'Beeston [Hutchinson], Christopher (1579/80-1638)', The Oxford Dictionary of National Biography (Oxford, 2004), 4:826-7. 
2 N.W. Bawcutt, 'Documents of the Salisbury Court Theater in the British Library', Medieval and Renaissance Drama in England 9 (1997), 186.

3 Undated petition to the House of Lords, quoted by Bentley, The Jacobean and Caroline Stage, 6:67.

4 N.W. Bawcutt (ed.), The Control and Censorship of Caroline Drama: The Records of Sir Henry Herbert, Master of the Revels, 1623-73 (Oxford, 1996), 200.

5 Herbert corroborates Heton's account: 'I disposed of [Richard] Perkins, [John] Sumner, [William] Sherlock and [Anthony] Turner, to Salisbury Court, and joynd them with the best of that company' (Bawcutt, Control and Censorship, 201).

6 Bentley, The Jacobean and Caroline Stage, 6:66-8.

7 Andrew Gurr, The Shakespearian Playing Companies (Oxford, 1996), 9, 96, 156, 383, 423. J.P. Collier seems first to have articulated this idea: 'We are to understand, therefore that at this date Christopher Beeston separated himself from the Queen's players, at whose head he had been for some years, in order to undertake the charge and instruction of an independent company of juvenile performers, hereafter called the King's and Queen's Young Company' (my italics), The History of English Dramatic Poetry ... and Annals of the Stage, 3 vols (London, 1831), 2:78.

8 Martin Butler, 'Exeunt Fighting: Poets, Players, and Impresarios at the Caroline Hall Theatres', Localizing Caroline Drama: Politics and Economics of the Early Modern English Stage, 1625-1642, Adam Zucker and Alan B. Farmer (eds) (New York, 2006), 111-12.

9 Bawcutt, Control and Censorship, 177, 181, 191

10 Ibid, 146, 164-5, 167, 173, 262-4.

11 Ibid, 149.

12 Ibid, 181.

13 Bentley, The Jacobean and Caroline Stage, 6:63; Philip Edwards, 'The Managers of the Public Theatres', Revels History of Drama in English, vol. 4: 1613-1660 (London, 1981), 29; David Stevens, 'Christopher Beeston: A Jacobean/Caroline Theatrical Impresario', Odyssey 7 (1984), 55.

14 Linda Levy Peck, Court Patronage and Corruption in Early Stuart England (Boston, 1990), 1-29; Richard Grassby, The Business Community of Seventeenth-Century England (Cambridge, 1995), 103-4, 127-8.

15 On the Herbert family's use of the word 'friend', see Jeffrey Powers-Beck, Writing the Flesh: The Herbert Family Dialogue (Pittsburgh, 1998), 13-16.

16 F.H.W. Sheppard (ed.) Survey of London XXXVI: The Parish of St. Paul Covent Garden (London, 1970), 27-34, 230. An invective by William Prynne describes the lessees as Catholic monopolists: 'All her Majesties servants, who doe suck the marrow of our estate ... when they first came hither they were but poore beggers, \& now they keep 
Coaches: what houses have they built in the Covent-garden, and what faire houses do they built in Lincoln In-fields? [sic]', Hidden Workes of Darkenes Brought to Publike Light (London, 1645), 196.

17 The leases purchased by 'Christopher Hutchinson', 'gentleman' of 'St Giles in the Fields' are catalogued in 'Appendix III: Leases of the Piazza and Surrounding Streets within the Area of the Brick Boundary Wall, 1631-37' in Sheppard, Survey of London XXXVI, 298-9, fig. 45.

18 E.A.J. Honigmann and Susan Brock (eds), Playhouse Wills, 1558-1642 (Manchester, 1993), 191-4. Beeston's will also records his purchase of a piece of ground 'inclosed with a Brick wall' in Lincoln's Inn Field, likely one of thirty-two plots on Purse Field, a few hundred feet from the Cockpit, then being developed by the Bedfordshire gentleman, William Newton. Like Beeston, Newton was a lessee in Henrietta Street, Covent Garden. He also oversaw the rebuilding of Great Queen Street in 1635, a half block north of the Cockpit. See W. Edward Riley and Sir Laurence Gomme (eds), Survey of London III: The Parish of St. Giles-in-the-Fields, Part 1, Lincoln's Inn Fields (London, 1912), 9-16.

19 His second tenant in 1634 (at 6 Henrietta St) was William Monson, Viscount Castlemaine. This was a son of Sir William Monson, Vice Admiral of the royal navy and an associate of Beeston's close friend Captain Lewis Kirke, a further indication that personal connection factored into Beeston's tenant selection.

20 G.E. Cokayne (ed.), The Complete Peerage (London, 1945), 10:643-4; The Dictionary of Welsh Biography Down to 1940 (London, 1959), 778-9.

21 The baron wrote to Sir Henry Vane on 5 November 1630: 'I thank God we are free men now and look and laugh at the follies of others... . I wish you here that we might be merry together and laugh at plays unto which we are much given, for seldom there passeth a week without a play or two; there was never such subject for mirth and laughter as now, and we may now be merry at a play without danger.' In this context, 'plays' is clearly code for 'spectacular conflicts between court factions' but the metaphor hints at an interest in the stage, Calendar of State Papers, Addenda 1625 to 1649 (London, 1897), 381-2.

22 Habington wrote verses commending two of Shirley's Cockpit plays in quarto, The Wedding (1629) and The Grateful Servant (1630). Powis's daughter, Lucy, was the model for 'Castara' in Habington's lyrical poems. See Kenneth Allot (ed.), The Poems of William Habington (Liverpool, 1948), xxii-xxix.

23 Cokayne, Complete Peerage, 10: 643-4.

24 George Garrard to the Earl of Strafford (9 January 1633/34), in William Knowler (ed), The Earl of Strafforde's Letters and Dispatches (Dublin, 1740), 1:177-8.

25 Gerrard to Strafford (7 February 1637), Strafforde's Letters, 2:147. 
26 Garrard to Strafford (3 June 1634 and 24 June 1635), Strafforde's Letters, 1:262-3, 435.

27 The property is described in the 'Survey of Certain Lands and Tenements scituate and being at Pickadilly, the Blue Muse, and others thereunto adioyninge'(1650), in Peter Cunningham, Handbook for London, Past and Present (London, 1849) 2:738. Its location is shown on Faithorne and Newcourt's map of 1658, reproduced in F.H.W. Sheppard (ed), Survey of London XXXI The Parish of St. James Westminster Part Two, North of Piccadily (London, 1963), plate 2. The earl of Clarendon met the earl of Bedford there in 1641 to discuss the fate of Strafford and remembered it as 'a fair house for entertainment and gaming, with handsome gravel walks with shade, and where were an upper and lower bowling-green, wither very many of the nobility and gentry of the best quality resorted, both for exercise and conversation', The History of the Rebellion and Civil Wars in England (Oxford, 1826), 1:422.

28 NA C3 423/42 (Berrowes v Osbaldestone, 16 May 1643). John Barrowe, one of the project's investors, claimed the cost was 'ffive thousand Poundes and upwards'.

29 NA C2 ChasI/P6/6 (Phillipps v Beeston, 16 February 1641/42).

30 NA C2 ChasI/P6/6. Beeston's counter bond was to protect him should Osbaldeston fail to repay Danvers. It happened that Osbaldeston honoured the terms of neither the original bond nor the counter bond and Danvers pursued Elizabeth Beeston for the money in the Court of Common Pleas after her husband's death.

31 Pembroke arranged his offices of knight harbinger on 30 September 1629 (NA SP 16/149, f 111) and keeper of the king's gardens in April 1630 (NA LC 5/132, f 252).

32 On 30 September 1629, Pembroke secured "John Barrow ... a falconer's place" (NA SP 16/149, f 109). On Pembroke and the forest of Dean, see Cyril Hart, The Forest of Dean: A New History 1550-1818 (Phoenix Mill, 1995), 62, 79.

33 Sean Kelsey, 'Danvers, Sir John, (1584/85-1655)' The Oxford Dictionary of National Biography, 15:101-3.

34 Gerrard to Strafford (24 June 1635), Strafforde's Letters, 1:435; Gerrard to Edward, Viscount Conway, 30 May 1636 (NA SP 16/322, f 41).

35 A list of 'speaking persons' in the 1637 quarto of Thomas Nabbes's Hannibal and Scipio ('acted in 1635') identifies younger men with each of its leading heroic parts: William Allen (Hannibal), Michael Bowyer (Scipio), Hugh Clarke (Nuntio, Syphax) and Theophilus Bird (Massanissa). By contrast, their older colleagues Richard Perkins (Hanno), William Sherlock (Maharball, Prusias), and John Sumner (Himulco) appear infrequently (A4r). Henry Glapthorne commemorates Fenn's ability to evoke 'Innocence and timorous Modestie' in women's parts in 'For Ezekiel Fen at his first Acting a Mans Part', Poems (London, 1639), 28. 
36 Thomas Nabbes, Hannibal and Scipio (London, 1637), E1v; James Shirley, The Dukes Mistris (London, 1638), D1r-D1v; John Ford, The Fancies Chaste and Noble (London, 1638), D2r, F2v, K4r; Henry Glapthorne, The Hollander (London, 1640), H1r-v. For the licenses, see Bawcutt, Control and Censorship, 196-8.

37 An idea first proposed by William B. Markward in his PhD dissertation, A Study of the Phoenix Theatre in Drury Lane, 1617-38 (University of Birmingham, 1953), 143-6.

38 Gurr, Shakespearian Playing Companies, 424. Richard Perkins, Anthony Turner, John Sumner, and William Sherlock formed the nucleus of the new Queen's Men at the Salisbury Court theatre. The King's Men absorbed Michael Bowyer, William Allen, William Robins (Robinson) and Hugh Clarke, while Theophilus Bird, Ezekiel Fenn, John Page, Robert Axen, and George Stutville remained with Beeston. Five or more actors were drawn from other companies: William Trigg and Nicholas Burt from the King's Men; Edward Gibbs from the King's Revels; and Samuel Mannery and John Wright from the Prince's Men. By 1639, Michael Mohun, John Lacy, Edward Davenport, and Robert Cox had also joined. Andrew Pennycuicke later professed to being 'the last that Acted Matilda' in Robert Davenport's King John and Matilda (London, 1655, A2v) so was probably also a recruit between 1639 and 1642.

39 By 'Beeston's boyes,' Herbert appears to mean 'the youths Beeston has brought to court.' The definite article in his second notation — 'the B. boyes' - may imply William Beeston's presence (ie 'the Beestons's boys').

40 The roster of the young company London playgoers saw in October 1637 was considerably altered by the incorporation of actors from other companies. Herbert's usual designation from this point was simply 'Cockpit Company'. Printed plays refer to 'their Majesties Servants' and 'the servants to both their Majesties', never (to my knowledge) to 'Beeston's Boys'.

41 Bawcutt, Control and Censorship, 200-1. In the first play, a Priest of Cupid leads 'four young men and Maydes' onstage where their 'feete / in an euen Measure meet' and 'cheerfull voices rise' to celebrate the love deity, John Fletcher, Cupids Reuenge (London, 1630), B4r-v. The second play concludes with a group of youths ('Enter Musitions, Fount, Hare. Bell) serenading Lady Hartwell; Valentine cues the song: 'come boy sing the song I taught you, / And sing it lustily ... thou hast got the start boy, / But ile so tumble after, come my friend leade, / Lead chearefully, and let your fiddles ring boyes', Francis Beaumont and John Fletcher, Wit without Money (London, 1640), I3v.

42 On 13 February 1636/37, the Venetian ambassador noted that the queen was 'near her delivery [of princess Anne] and she imagines that it will not turn out well in any other house but St. James's', Calendar of State Papers Venetian, 1636-1639 (London, 1923), 
147. As Butler has pointed out, she acknowledged Beeston's young troupe soon after with a grant of $£ 30$ for its maintenance. The declared accounts of the queen's treasurer record the gift, which was discovered by Karen Britland ('Exeunt Fighting', 112, 126 n52). The entry is as follows: 'Christofer Beeston Maister of a Company of Boyes of the Revells newely erected for the king and Queenes service by her Maiesties Warrant dated the $\mathrm{xx}^{\text {th }}$ of ffebruary 1636 in consideracion of his Chardges and paines in breeding and keeping them all the tyme of the sicknes as by the said Warrant together with his Acquitance dated the xxviij th of ffebruary 1636 may appear for the receipt—xxx ${ }^{1}$, (National Library of Wales, Wynnstay MS 181, f 15v).

43 Malone Society Collections, 2.3:326-7. For the offices overseen by the Lord Chamberlain, see G.E. Alymer, The King's Servants: The Civil Service of Charles I, 1625-1642 (London, 1974), 473 and passim.

44 Analogous warrants established Lodowick Carlisle as the Master of Bows on 29 September 1635 and Joseph Taylor as Yeoman of the Revels on 29 September 1639 (Malone Society Collections, 3.2:377, 391). Records entitled 'Revels Allowances' (25 May 1636) and 'Allowance vnto Officers of the Reuells' (13 February 1636/37) show that the Master of the Revels earned a monthly stipend of $£ 12$, the Clerk Comptroller, the Clerk, and Yeoman $£ 3$ 6s 8d, and the Groom $£ 113$ s $4 \mathrm{~d}$ (Malone Society Collections, 3.2:379, 381).

45 When William Beeston was sworn in after his father's death, the title was expanded to 'Gouuernor \& Instructer of the Kings \& Queens young Company of Actors' (Malone Society Collections, 2.3:389).

46 John H. Astington, English Court Theatre, 1558-1642 (Cambridge, 1999), 27-8.

47 Malone Society Collections, 3.2:395.

48 The council's warrant reads: 'A warrant to Jaspar Heyley and some of $\mathrm{y}^{\mathrm{e}}$ Messengers to fetch before the Lords Christopher Beeston William Beeston Theophilus Bird, Ezekiel Fenn and Michaell Moone with a clause to Cummand the Keepers of ye Playhouse called $y^{\mathrm{e}}$ Cockpit in Drury Lane that either live in it or haue relacion to it not to permit Plaies to bee acted there till further ordre' (NA SP 16/356, f 111); Beeston's response is undated, but belongs to May 1637 (NA SP 16/339, f 7).

49 Bawcutt, 'Documents of the Salisbury Court Theater', 186-8.

50 Heton seems to have owed his theatrical standing to his position as 'one of the Sewers of the Chamber to or deare Consort the Queene' (Bawcutt, 'Documents of the Salisbury Court Theater', 187). Taylor, a leader in the King's Men, was appointed Yeoman of the Revels in 1639 (see $\mathrm{n} 44$ ). On the importance of social connection to the success of earlier Jacobean entrepreneurs, see S.P. Cerasano, 'The Patronage Network of Philip Henslowe and Edward Alleyn', Medieval and Renaissance Drama in England 13 (2001), 82-92. 